\title{
DỨBin
}

Technological University Dublin

ARROW@TU Dublin

\section{ReSearcher Suite: selection and implementation - the Hosted Option}

\author{
Niamh Walker-Headon \\ Technological University Dublin, niamhheadon@gmail.com
}

Follow this and additional works at: https://arrow.tudublin.ie/ittsupart

Part of the Library and Information Science Commons

\section{Recommended Citation}

Walker-Headon, N. ReSearcher Suite: selection and implementation-the hosted option Library Hi Tech News 27 (2), 1-5, 2010. DOI: 10.1108/07419051011050402

This Article is brought to you for free and open access by the Support Services at ARROW@TU Dublin. It has been accepted for inclusion in Articles by an authorized administrator of ARROW@TU Dublin. For more information, please contact arrow.admin@tudublin.ie, aisling.coyne@tudublin.ie,gerard.connolly@tudublin.ie.

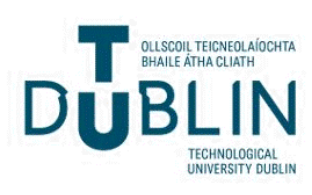




\section{Background}

Library, Institute of Technology Tallaght, is a small academic library serving a registered user population of $4400+$ with the equivalent of 10 FTE staff. The Library uses the Millennium library management software from Innovative Interfaces Inc. (III). The Institute of Technology Tallaght is a young organization, having first opened its doors to students in 1992/3. Consequently, there is not a large stock of journals, books or other print materials. Every effort is made to provide access to materials online, within the capabilities of the resources available to the library.

\section{Needs Assessment For Federated Searching}

Since 2003, access to online subscriptions is provided via the III web access management module using the proxy rewrite method. Online resources have been highlighted in user education sessions, but patrons needed a better way of accessing them, at the journal level. As an interim solution, it was decided to do occasional loads of MARC records for e-journals and see if this increased the usage of the resources.

The library, not in a position to subscribe to Serials Solutions (Brown and Smyth 2005), used MARC 21 records from vendors where available or the CUFTS2MARC service hosted by Simon Frasier University (SFU). Otherwise where .csv files were available, MARC edit was used to create skeleton records. Several databases and ejournal

This article is ( ) Emerald Group Publishing and permission has been granted for this version to appear here (http://arrow.dit.ie/itt/). Emerald does not grant permission for this article to be further copied/distributed or hosted elsewhere without the express permission from Emerald Group Publishing Limited. The published article is available at:

http://www.emeraldinsight.com/journals.htm?issn $=0741-9058 \&$ volume $=27 \&$ issue $=2 \&$ articleid $=1858832$. 
collections were loaded into the library catalog. The addition of these records allowed patrons to search the catalog for journal titles by subject access and increased the usage of the online resources. However, it did not allow article level searching or linking, which became one of the most frequent requests from researchers to the library. When the library website was redesigned, an electronic resources web page, indicating subject areas for databases, was created. However, it did not fill the needs identified in the road map for library development for open URL linking, coverage data, and a federated search engine.

Several federated search products available in the marketplace were examined, several presentations given by vendors about federated search engines were attended by staff, and research in this area was undertaken (Mohamed and Hassan 2008), (Parry 2009), (Boyd et al. 2006). It was decided to concentrate on open source options. The Library had been successfully using open source / freeware software since 2004, including LibX toolbar, Wink, MARC Edit and Library Linky.

The publication in Library Hi-Tech of an article about the development of the federated search engine module of the reSearcher Suite at SFU (Mah and Stranack 2005), led to this option being investigated, particularly when we had successfully used their records for e-journals coverage for a few years, with a good response time to queries from SFU.

This article is ( ) Emerald Group Publishing and permission has been granted for this version to appear here (http://arrow.dit.ie/itt/). Emerald does not grant permission for this article to be further copied/distributed or hosted elsewhere without the express permission from Emerald Group Publishing Limited. The published article is available at:

http://www.emeraldinsight.com/journals.htm?issn $=0741-9058 \&$ volume $=27 \&$ issue $=2 \&$ articleid $=1858832$. 
It became evident that an electronic resource management tool and a federated search engine are essential if the library is to get the most out of its online subscriptions and meet the requirements of license agreements. The reSearcher suite was identified as the best fit for our organizational needs on the basis of: cost, providing an open source solution, hosting and support being available from SFU without the need for in-house technical support, having a positive experience with CUFTS2MARC, and interoperability with III software for patron validation.

The reSearcher suite provides seamless searching of the library's holdings, both print and electronic, in a single user-friendly interface. This is an open source software, and combined with the remote hosting option provides a significant cost saving on the equivalent III product - the MAP Suite. (Myhill 2004). The GODOT module's Inter Library Loan (ILL) capabilities, Open URL linking and z39.50 searching should potentially reduce the number of ILLs applied for, and easily identify where there is access to items via existing subscriptions. In 2008, requests for items we had access to, accounted for $7 \%$ of all ILL requests.

There are two major deliverables with ReSearcher. First, the quality of information retrieval is greatly improved. Second, it provides an easy introduction to the world of peer reviewed research for undergraduates. Undergraduates are using Google as a first step, and in some cases students are paying for articles they locate via Google

This article is ( ) Emerald Group Publishing and permission has been granted for this version to appear here (http://arrow.dit.ie/itt/). Emerald does not grant permission for this article to be further copied/distributed or hosted elsewhere without the express permission from Emerald Group Publishing Limited. The published article is available at:

http://www.emeraldinsight.com/journals.htm?issn $=0741-9058 \&$ volume $=27 \&$ issue $=2 \&$ articleid $=1858832$. 
which they should be able to access via the library free of charge (Taylor 2007), (Kesselman and Watstein 2005)

Table 1 ReSearcher / III Millennium MAP suite module comparison

\begin{tabular}{|l|l|}
\hline III Map Suite & ReSearcher \\
\hline Electronic resource management & CUFTS \\
\hline CASE coverage load & CUFTS \\
\hline WebBridge & GODOT \\
\hline Research Pro & dbWIZ \\
\hline
\end{tabular}

While reSearcher does not integrate into Millennium as completely as the MAP suite, searches can't be saved to accounts, acquisitions functions aren't integrated, and statistics aren't as detailed as for direct access via Web Access Management, as examples, the patron functionality is strong enough to deliver what our patrons are looking for.

\section{reSearcher Functionality and Benefits}

The reSearcher Suite is composed of three main elements, which closely mirror III products. The CUFTS module provides a searchable knowledge base of the full-text journals collection, coverage data via skeleton MARC 21 records in the library catalog, This article is $\odot$ Emerald Group Publishing and permission has been granted for this version to appear here (http://arrow.dit.ie/itt/). Emerald does not grant permission for this article to be further copied/distributed or hosted elsewhere without the express permission from Emerald Group Publishing Limited. The published article is available at:

http://www.emeraldinsight.com/journals.htm?issn $=0741-9058 \&$ volume $=27 \&$ issue $=2 \&$ articleid $=1858832$. 
and electronic resource management tools including: license administration, financial management along with alerts of subscription renewal dates, and statistics collection. The GODOT module leverages the CUFTS knowledge base to provide direct links to full-text articles using direct OpenURL link resolving, to and from the library's subscriptions, providing immediate access to full text articles. Patrons do not search every resource for every citation they seek. GODOT populates interlibrary loan application forms from a citation online that eliminates human error at the data entry point and the need for double entry of requests. The module also validates against the library server for authentication and submission of requests directly into the Millennium ILL module. The DBWIZ module is a federated search engine with basic and advanced searching across multiple databases, websites, catalogs, and other online resources from a single interface, presenting results in an integrated results list. DBWIZ provides a simple search box that can be put onto any page and groups resources into profiles.

ReSearcher will help with the administration of and access to all the library's subscription resources. Electronic resource management elements of CUFTS will allow for better access to our subscription information, including: dates for renewals, costs, email reminders in advance of renewals, vendor contact details, details of licenses such as limitations on use and number of simultaneous users, and subscription renewal alerts. Improved access to print and electronic resources is another benefit which results in better quality research, a more attractive research environment for potential students, enhanced quality of the library service, and easier resource discovery and

This article is ( ) Emerald Group Publishing and permission has been granted for this version to appear here (http://arrow.dit.ie/itt/). Emerald does not grant permission for this article to be further copied/distributed or hosted elsewhere without the express permission from Emerald Group Publishing Limited. The published article is available at:

http://www.emeraldinsight.com/journals.htm?issn $=0741-9058 \&$ volume $=27 \&$ issue $=2 \&$ articleid $=1858832$. 
identification. This results in a reduced gap in access to information between our patrons and those in the University sector and creates a positive view of the library by students and faculty.

ReSearcher provides seamless searching of the library's holdings, both print and electronic, in a single user-friendly interface. A Google-like search box can be put on any online page, including Moodle. MARC records for electronic journals holdings with URLs in the records, provides direct linking to the online journals. Print journal titles are loaded into the journals $A-Z$ listing and there is seamless access to additional open access and free resources. The opportunity to change the submission of ILL requests to an online system results in a possible reduction in staff time needed to administer the service. The ease of use of ReSearcher results in better information literacy training for first year students. Other benefits include use of the existing connectivity via http on port 80 and z39.50 technology, and to use a solution already in use by other III customers.

\section{ReSearcher Implementation}

A proposal outlining the benefits of open URL linking, coverage data and federated searching, addressing the III products mentioned above and the reSearcher Suite in comparison was prepared. At the local level, it received a positive response. The Institute Librarian was asked to bring the proposal to the attention of the other Institute This article is ( ) Emerald Group Publishing and permission has been granted for this version to appear here (http://arrow.dit.ie/itt/). Emerald does not grant permission for this article to be further copied/distributed or hosted elsewhere without the express permission from Emerald Group Publishing Limited. The published article is available at:

http://www.emeraldinsight.com/journals.htm?issn $=0741-9058 \&$ volume $=27 \&$ issue $=2 \&$ articleid $=1858832$. 
librarians to raise the possibility of a consortium deal. The proposal outlined locally hosting the reSearcher Suite versus SFU providing a hosted solution including support for the reSearcher Suite. The IT Manager advised that the hosted solution was a better option for a small organisation. When, by the start of 2009, there was no further movement on the proposal it was decided to revive it internally. In the first quarter of 2009 we explored the possibility of using VUfind instead (Houser, 2008 \& Ho et al., 2009) but it looked like there was no hosted solution. The article also outlined the need for significant local technical expertise in the area of PHP, Oracle, My SQL, etc. It was decided to stay with the original proposal as no local technical support would be required.

Patron comments from the survey results of the 2009 LibQual+ survey included observations that patrons' friends attending other colleges and universities in the greater Dublin area were able to do article level searching, and they could not understand why this was not available to them. Consequently, it was decided to go ahead with the acquisition of the entire reSearcher Suite hosted at SFU with support.

Implementation began in April 2009 with an implementation team composed of the systems librarian and the serials specialist, who also has a role in library website administration. Additional staff helped with the gathering of license information, tagging of journals and testing as needed. Some functionality was available immediately. After

This article is ( ) Emerald Group Publishing and permission has been granted for this version to appear here (http://arrow.dit.ie/itt/). Emerald does not grant permission for this article to be further copied/distributed or hosted elsewhere without the express permission from Emerald Group Publishing Limited. The published article is available at:

http://www.emeraldinsight.com/journals.htm?issn $=0741-9058 \&$ volume $=27 \&$ issue $=2 \&$ articleid $=1858832$. 
implementation there should be time efficiencies in the areas of database administration, user education, and interlibrary loans.

Implementation began with the CUFTS module. Local resources were enabled from a list on the maintenance interface creating the searchable Journals $A-Z$ and the Database A-Z. Subjects were allocated to resources to create the subject listing on the Database A-Z. Journal tags already established were added by SFU. Additional journals were tagged by the subject specialists locally. The electronic resource management (ERM) section took the longest; as information had to be gathered and collated for each subscription resource, including licensing, financial, and renewal details, the location of online statistics, help contacts, and online help for users. Once the functionality was implemented the user interface web page templates needed editing. Cascading style sheets (css), and html web pages were involved, requiring html and css knowledge to complete this element. This allowed the look and feel of the library web site to be mirrored on reSearcher. The CUFTS module was rolled out to library staff in June 2009.

The GODOT module queries OpenURL targets and the CUFTS open knowledge base. While contacting the resource suppliers about licensing information, openURL linking was enabled where offered by the supplier. In parallel to erm details being entered into CUFTS, the implementation of GODOT and dbWiz went ahead. Again, the user web pages were edited to mirror our library web site. Most importantly however GODOT was

This article is ( ) Emerald Group Publishing and permission has been granted for this version to appear here (http://arrow.dit.ie/itt/). Emerald does not grant permission for this article to be further copied/distributed or hosted elsewhere without the express permission from Emerald Group Publishing Limited. The published article is available at:

http://www.emeraldinsight.com/journals.htm?issn $=0741-9058 \&$ volume $=27 \&$ issue $=2 \&$ articleid $=1858832$. 
able to validate against our Millennium library system to allow the submission of ILL requests directly into the library system. This took some time to sort out, and the assistance of III and SFU. The copyright requirements of the British Library meant that we had not offered our users this option previously. After consultation with the British Library and confirmation from our IT Manager it was established that the validation form would suffice to gather an electronic signature. The GODOT functionality was rolled out to all library users in August 2009. Traditional ILL processes were replaced with the GODOT search form that integrates seamlessly into the library opac. The icon "Where can I find this?" was added to all open URL compliant resources to provide a link to search for full text articles from within the resource, obviating the need to repeat the search.

DbWiz implementation was the quickest of the modules to complete. Local subscriptions were identified from a list and enabled. Authentication details, where needed, were entered into the dbWiz maintenance interface. Groupings of resources, called profiles, were made based on general subject areas. Where a resource is not searched by dbWiz, a link to GODOT is integrated into the search results, giving combined access to results from all almost all subscriptions, as well as to selected open access and free resources. When implementing, it was decided to only list 20 results from each database in the result set. Users click on a link in the full results list to take the search to the database in question if they need to see the full set. A search box for each profile was created and put on the library downloads page for use by other This article is $($ Emerald Group Publishing and permission has been granted for this version to appear here (http://arrow.dit.ie/itt/). Emerald does not grant permission for this article to be further copied/distributed or hosted elsewhere without the express permission from Emerald Group Publishing Limited. The published article is available at:

http://www.emeraldinsight.com/journals.htm?issn $=0741-9058 \&$ volume $=27 \&$ issue $=2 \&$ articleid $=1858832$. 
departments. In addition, the dbWiz search box was added to the library web site on the homepage, the subject portals, and to the library's Moodle courseware (see screenshot below).

\section{dbWiz search box on the Library homepage}

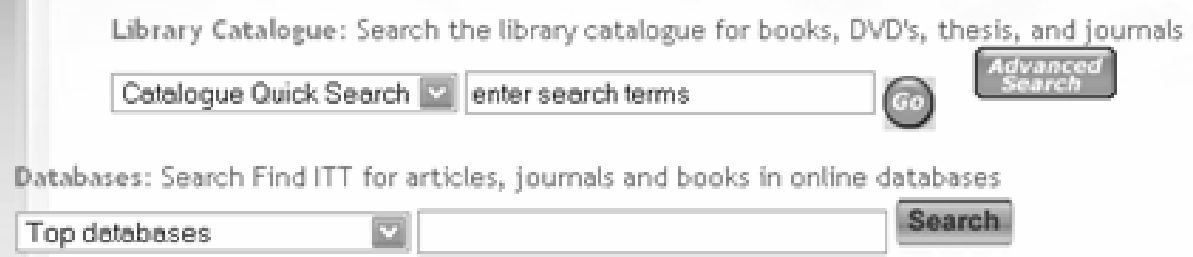

(Put exact s00X ORARTicLE TITLE searches in inverted commas)

The final part of the project was to create online help pages that would be logical and user friendly. It was decided to use javascript to frame the help information on the different elements of the reSearcher suite and keep them all on the one page. This page gives a step-by-step outline of what each module can do for the user and what resources exactly are searched (see screenshot below).

This article is (c) Emerald Group Publishing and permission has been granted for this version to appear here (http://arrow.dit.ie/itt/). Emerald does not grant permission for this article to be further copied/distributed or hosted elsewhere without the express permission from Emerald Group Publishing Limited. The published article is available at:

http://www.emeraldinsight.com/journals.htm?issn $=0741-9058 \&$ volume $=27 \&$ issue $=2 \&$ articleid $=1858832$. 


\section{Find IIT Help}

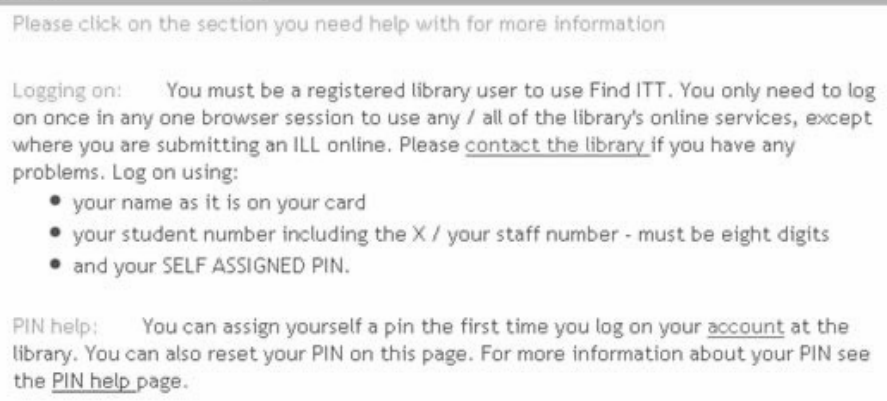

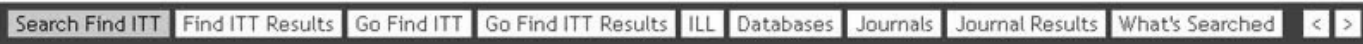

Searching Find ITT

You can search Find ITT, using the basic search function, from the library's home page, using the second search box. Select the pre-selected subject area you want to search and enter your search words. This can be your topic, the title of an article, names of people, anything you want in fact. If you want to search for the exact title put it in inverted commas. ("Reflecting on the strategy process"). This will give you fewer more accurate results. Click on Search and Find ITT searches across the relevant databases for you. Before you can view your search results, you will have to log on to your library account. Please see the section above on logging on. Every subject area includes the library catalogue in it's results. Because Find ITT is searching multiple databases at once it can take a minute or two for the

During the entire process, communication from SFU was speedy, and problem solving was fast and efficient. This made the process run smoothly and efficiently. Certainly there were some issues that could not be resolved immediately. The normal turn-around time was less than 24 hours. Different SFU staff work on different modules, having one staff member as the main co-ordinator helped immensely with this process.

\section{reSearcher Launch, Feedback, and Next Steps}

GODOT was launched at the beginning of August. There was a soft launch of the entire reSearcher suite in September 2009. Students received an introduction during their information literacy sessions. In response to feedback from students and staff several changes have been made: The color for the link to connect to databases was changed to red in the Database A-Z list; the number of tabs at the top of the reSearcher pages This article is $\odot$ Emerald Group Publishing and permission has been granted for this version to appear here (http://arrow.dit.ie/itt/). Emerald does not grant permission for this article to be further copied/distributed or hosted elsewhere without the express permission from Emerald Group Publishing Limited. The published article is available at:

http://www.emeraldinsight.com/journals.htm?issn=0741-9058\&volume $=27 \&$ issue $=2 \&$ articleid $=1858832$. 
was reduced; the results entries in dbWiz were reduced to make the links to full text and books stand out; and we added an explanation that the results are sorted by date by default. Additional assessment will take place next year during a planned usabilitytesting project for the library's web services.

We will continue to refine the look and feel of the reSearcher suite in response to user feedback and if possible work with SFU on the development of the suite. Statistics currently show that first year students have taken up searching with reSearcher, while at postgraduate level direct access via single databases followed by Google Scholar remains the most popular method of access. As postgraduate students need to undertake more focused research this is not surprising, however they will be targeted to receive information about what the suite can do for them. Resources not currently available to us on dbWiz will be added as they become available. Local procedures will be created to compliment the documentation supplied by SFU such as creating and uploading the print journals MARC 21 file, subscription renewal procedures, extracting statistics etc.

The development of the suite continues with the addition of functionality to work with COUNTER and SUSHI statistics that we are currently testing. Statistics will establish: who the users and non-users are, any increase in online resource usage, and the impact there has or has not been on the inter library loan service. As time and

This article is ( ) Emerald Group Publishing and permission has been granted for this version to appear here (http://arrow.dit.ie/itt/). Emerald does not grant permission for this article to be further copied/distributed or hosted elsewhere without the express permission from Emerald Group Publishing Limited. The published article is available at:

http://www.emeraldinsight.com/journals.htm?issn $=0741-9058 \&$ volume $=27 \&$ issue $=2 \&$ articleid $=1858832$. 
resources allow, we hope to create an online tutorial for each module to help users understand how the suite can help them in their research.

\section{References and Suggested Readings}

BOYD, J., HAMPTON, M., MORRISON, P., PUGH, P. \& CERVONE, F. 2006. The One-Box Challenge: Providing a Federated Search That Benefits the Research Process. Serials Review [Online], - 32. Available: http://www.sciencedirect.com/science/article/B6W634M0J4M6-1/2/932bddf79cc80eeeea14ab367907ecc7. (accessed 11 January 2010)

BROWN, A. \& SMYTH, N. 2005. Serials Solutions and LinkFinderPlus at the University of Wales Swansea. Program: Electronic Library and Information Systems [Online], 39. Available: http://www.emeraldinsight.com/10.1108/00330330510595724. (accessed 11 January 2010)

GUNNLAUGSDOTTIR, J. 2008. As you sow, so you will reap: implementing ERMS. Records Management Journal [Online], $18 . \quad$ Available: http://www.emeraldinsight.com/10.1108/09565690810858497. (accessed 11 January 2010)

HARTMAN, K. A. \& MULLEN, L. B. 2008. Google Scholar and academic libraries: an update. New Library World [Online], $109 . \quad$ Available: http://www.emeraldinsight.com/10.1108/03074800810873560. (accessed 11 January 2010)

HO, B., KELLEY, K. \& GARRISON, S. 2009. Implementing VuFind as an alternative to Voyager's WebVoyage interface: One library's experience. Library Hi Tech [Online], 27. Available: http://www.emeraldinsight.com/10.1108/07378830910942946.

HOUSER, J. 2009. The VuFind implementation at Villanova University. Library Hi Tech [Online], 27. Available: http://www.emeraldinsight.com/10.1108/07378830910942955. (accessed 11 January 2010)

KESSELMAN, M. \& WATSTEIN, S. B. 2005. Google Scholar ${ }^{\mathrm{TM}}$ and libraries: point/counterpoint. Reference Services Review [Online], 33. Available: http://www.emeraldinsight.com/10.1108/00907320510631535. (accessed 11 January 2010)

KHURSHID, Z. \& AHMED, S. S. 2007. From online catalogs to library portals: empowering users. Vine [Online], $37 . \quad$ Available: http://www.emeraldinsight.com/10.1108/03055720710825609. (accessed 11 January 2010)

This article is ( ) Emerald Group Publishing and permission has been granted for this version to appear here (http://arrow.dit.ie/itt/). Emerald does not grant permission for this article to be further copied/distributed or hosted elsewhere without the express permission from Emerald Group Publishing Limited. The published article is available at:

http://www.emeraldinsight.com/journals.htm?issn $=0741-9058 \&$ volume $=27 \&$ issue $=2 \&$ articleid $=1858832$. 
MAH, C. \& STRANACK, K. 2005. dbWiz: open source federated searching for academic libraries. Library $\mathrm{Hi}$ Tech [Online], 23. Available: http://www.emeraldinsight.com/10.1108/07378830510636292. (accessed 11 January 2010)

MOHAMED, K. A. \& HASSAN, A. 2008. Web usage mining analysis of federated search tools for Egyptian scholars. Program: electronic library and information systems [Online], 42. Available: http://www.emeraldinsight.com/10.1108/00330330810912098. (accessed 11 January 2010)

MUIR, S. P. 2005. An introduction to the open source software issue. Library Hi Tech [Online], 23. Available: http://www.emeraldinsight.com/10.1108/07378830510700678. (accessed 11 January 2010)

MYHILL, M. 2005. A MAP for the library portal: through the labyrinth of online information sources. Online Information Review [Online], 29. Available: http://www.emeraldinsight.com/10.1108/14684520510583918. (accessed 11 January 2010)

PARRY, M. 2009. After Losing Users in Catalogs, Libraries Find Better Search Software. Chronicle of Higher Education [Online], 56. Available: http://chronicle.com/article/After-Losing-Users-in/48588/ (accessed 11 January 2010)

STRANACK, K. 2008. The reSearcher Software Suite: A Case Study of Library Collaboration and Open Source Software Development. Serials Librarian [Online], 55. Available: http://www.informaworld.com/10.1080/03615260801970824 (accessed 11 January 2010)

TAYLOR, S. 2007. Google Scholar - friend or foe? Interlending \& Document Supply [Online], 35. Available: http://www.emeraldinsight.com/10.1108/02641610710728122. (accessed 11 January 2010)

This article is (c) Emerald Group Publishing and permission has been granted for this version to appear here (http://arrow.dit.ie/itt/). Emerald does not grant permission for this article to be further copied/distributed or hosted elsewhere without the express permission from Emerald Group Publishing Limited. The published article is available at:

http://www.emeraldinsight.com/journals.htm?issn $=0741-9058 \&$ volume $=27 \&$ issue $=2 \&$ articleid $=1858832$. 